\title{
PLINY THE ELDER AND MUCIANUS
}

The thirty-two fragments uniquely preserved by the elder Pliny from the writings of Vespasian's famous general Licinius Mucianus on mirabilia and other things are analysed in detail for their content and language. Some deductions about Mucianus' place of exile, the exact nature of his book, and Pliny's own use of it are at variance with those of other scholars, notably Syme. Pliny's varying attitudes towards Mucianus in the $\mathrm{NH}$ are explained in terms of tensions between Mucianus and Titus, with this having some bearing on the circumstances and date of Pliny's own book.

As is well known ', Licinius Mucianus was kingmaker in the year 69, instrumental in putting Vespasian (an old enemy, ironically) upon the throne, a classic compound of vices and virtues, a consummate political operator and cynic, a man cui expeditius fuerit tradere imperium quam obtinere ${ }^{2}$.

Nearer to the present theme, Mucianus was also a person of pronounced intellectual and literary interests and abilities. According to Tacitus, in a passage (Dial. XXXVII 2) which certifies that he was still alive in 75 , he collected, studied, and edited ancient documents. This in itself would strike a chord with Pliny who (XIII 83) speaks of his own inspection of papers written in the hand of Tiberius and Gaius Gracchus at the house of someone else who combined polite letters with a career, the poet Pomponius Secun-

1 The facts of Mucianus' life and career are deployed with panoply of primary source materials by L. Petersen in PIR V, Berlin 1970, L 216. See also G. E. F. Chilver, $A$ Historical Commentary on Tacitus' Histories I and II, Oxford 1979, p. 62. Syme's various contributions are discussed below; both he and Chilver enthuse over the sketch of Mucianus by E. Courbaud, Les Procédés d'art de Tacite dans les Histoires, Paris 1918, p. 173. To minimise superfoetation of secondary references, readers are directed to G. Serbat, «Pline l'Ancien. Etat présent des études sur sa vie, son oeuvre et son influence", $A N R W$ II 32, 4, Berlin \& New York 1986, pp. 2069-2200, for full bibliographical repertoire; cf. Z. Kádár, "Die Anthropologie des Plinius Maior», in the same volume, pp. 2201-24. All plain parenthetic references in the text of the present paper are to the $\mathrm{NH}$ of Pliny.

${ }_{2}$ Tacitus, Hist. I 10, an unimprovable vignette in terms of economy and epigram, though some allowance has to be made for its traditional blending of opposite qualities in the same person - one thinks easily of Cicero on Catiline and Livy on Hannibal. 
dus, whose biography was numbered amongst the polymath's various works ${ }^{3}$.

Mucianus also wrote a book or books in which there was much about the natural and unnatural curiosities that he had himself seen. These have largely to do with the East, where he had spent much time: in quasi-exile under Claudius, as governor of Lycia-Pamphylia, then in command of Syria and its legions ${ }^{4}$. Pliny drew extensively upon his writings, being as a consequence sole source for the thirty-two fragments which survive 5 .

Pliny also, it is worth subjoining ${ }^{6}$, quotes (XXXV 163) from a speech delivered by Mucianus in his second ${ }^{7}$ consulship (in 70) in which he denounced the gluttony and prodigality of Vitellius as spawning dishes as big as marshes (patinarum paludes). The witticism was characteristic of his style. A Byzantine epitome of Dio Cassius (LXV 2,5) has him fond of declaring that money is the sinews of power ${ }^{8}$. Such laconic humour is one of the features that will have endeared ${ }^{9}$ Mucianus to the equally crisp Vespasian. It is not a quality much in evidence in the extracts of Pliny, himself no slouch at sarcastic humour and cognate emotions stylishly expressed ${ }^{10}$, but it is one to be borne

${ }^{3}$ Inventoried along with valuable information of his uncle's career and literary work habits by the younger Pliny, Ep. III 5, to be read in conjunction with A. N. Sherwin-White, The Letters of Pliny: A Historical and Social Commentary, Oxford 1966, pp. 215-25. I am writing elsewhere on how and when the $\mathrm{NH}$ was composed.

${ }^{4}$ R. Syme, "Pliny the Procurator», HSCP 73, 1969, pp. 201-36 = Roman Papers II, Oxford 1979, pp. 742-73, an article of fundamental importance for many things, states as a fact that he was a legate in Armenia under Corbulo, but the passage of Pliny (V 83, not V 3 as Syme has it) in question says only that they were the two Romans who had most closely seen and described the source of the Euphrates. The notice in $P I R^{2}$ rightly mentions it as a possibility only.

5 They are assembled by H. Peter, HRR II, Leipzig 1906; repr. Stuttgart 1967, pp. 101-7.

${ }^{6}$ Being (quite properly) absent from Peter, the item tends to be overlooked.

7 As will be seen, Pliny frequently adorns his references to Mucianus with the label ter consul. All three consulships were suffect, the first in the mid-sixties, the third in 72 , not 74 as in Syme, art. cit., p. 203 (RP, p. 744).

${ }^{8} \mathrm{Cf}$. Appian, $B C$ IV 99, for the cognate remark that money is the sinews of war.

9 Others did not. Suetonius, Vesp. XIII, talks at some length about his dislike (and tolerance) of Mucianus' insolence (see later for more on this) and depraved private life, features borne out by Tacitus and Dio.

${ }^{10}$ For examples and discussion, see my forthcoming «Roman Emperors in the Elder Pliny». Just before introducing the snippet from Mucianus' conquestio on Vitellius, he himself had prefaced an item on that emperor's expenditure of one million sesterces upon a single bowl with at, Hercules, his favourite oath. Pliny emphatically does not deserve the sneering verdict of F. R. D. Goodyear in that largely futile titan, The Cambridge History of Latin Literature, pb. ed., Cambridge 1983, II 4, p. 176: «Here, better than in most other places, we may see the contortions and obscurities, the odd combinations of preciosity and baldness, and the pure vacuity to which rhetorical prose, handled by any but the most talented, could precipitously descend and would indeed often descend again». 
in mind when assessing the writings of Mucianus: how often were his stranger stories retailed with sly or overt scepticism or disbelief? ${ }^{11}$

Syme, not surprisingly, was drawn to Mucianus and often wrote about him, both in Tacitus and his multifarious articles ${ }^{12}$. But not always to good effect. Thus, in 'Pliny the Procurator', apart from the aforementioned false reference to Pliny and error over Mucianus' third consulship, we are told that he «held a picnic with a dozen companions under the shade of a vast plane tree». In point of fact, Pliny (XII 9) states that Mucianus feasted inside (intra) the giant tree with eighteen cronies. More seriously, Syme here repeats from Tacitus the quite misleading impression that Mucianus wrote only about curiosa and mirabilia. By cognate sin, Chilver ${ }^{13}$ equally misinforms in flatly referring to his writings as "works on geography". Now, it is true that Mucianus seems to have had a pronounced taste for bizarre items of the tabloid variety. But as will be seen, they were not his only interests. To what extent they dominated his writings is hard to say. We may be misled by Pliny's own selections. After all, if we knew the $\mathrm{NH}$ only from the eight mentions of it made by Aulus Gellius ${ }^{14}$, we would conclude that is was a ragbag of fantastic yarns and nothing else!

Syme also, seduced by Münzer ${ }^{15}$, sends his readers down another false trail in alleging that Pliny made more use of Mucianus than he let on, smuggling in items without acknowledging the source. He singles out as a specimen of this the passage (IX 52) about the fish of the Propontis and their habits. But Pliny acknowledges by name eighteen Roman sources (including Mucianus) and nine foreign ones in his own bibliography for book nine. The fact that he goes on to say that it is most convenient to use Greek names for these fish may imply a Greek source. And he cites other Roman ones by name on fish, e.g. Statius Sebosus at IX 46, Nepos and Laberius at IX 61, and Apicius at IX 66, not to mention the proconsular Asinius Celer at IX 67 and Trebius Niger (comes Luculli) at IX 90. Moreover, Pliny deserves to have it emphasised that he was by ancient standards notably scrupulous in acknowledging his debts, with the bibliographical inventories that accompany his résumés of each of the

"See later for disclosure with details of the important (albeit neglected by Syme) fact that Pliny more than once expresses his own doubts or incredulity over Mucianian material, and the possible inferences to be drawn from this.

12 Of the many mentions in Tacitus, Oxford 1958, see especially pp. 178, 231, 297. Apart from «Pliny the Procuraton, the most pertinent remarks are in «The March of Mucianus", Antichthon 11, 1977, p. 90 (RP III, p. 1011).

${ }^{13}$ Loc. cit.

${ }_{14}$ NA III 16, 22, 24; IX 4, 7, 13, 16; X 12, 1, 7; XVII 15, 6.

15 F. Münzer, Beiträge zur Quellenkritik der Naturgeschichte des Plinius, Berlin 1897, p. 392. 
books of the $N H$. Anyway, we all get most of what we first know from someone else. And no book can document each and every fact, otherwise it would become ludicrously gargantuan. Pliny himself (pref. 17) says that he had read two thousand books from which he garnered uiginti milia rerum dignarum cura, the latter claim if not the former being disarmingly modest ${ }^{16}$. As he remarks, quoting Domitius Piso, thesauros oportet esse, non libros.

According to Tacitus, when he fell under the displeasure of Claudius, Mucianus was in secretum Asiae sepositus. From the references (a dozen or so) to Cyzicus in the $\mathrm{NH}$ and Plinian use of Mucianus, Syme deduced that this was his place of refuge, dubbing it a «suitable residence for a snob and a voluptuary". But references to Cyzicus at (e.g.) XXXV 26 and 147 are explicitly linked by Pliny to Vipsanius Agrippa (memorably called illa torvitas) and to Varro. Cyzicus is clearly a possible choice, but not a necessary one. If Mucianus did elect it, we shall have to presume that it was a place much changed from the days of Tiberius who, according to Suetonius (Tib. XXXVII 3) and Tacitus (Ann. IV 36) had had to punish it by removal of its status of civitas libera because its citizens were committing acts of terrorism against Roman citizens. Both biographer and historian make no other mention of the place. Other choices were available, seemingly more congenial ${ }^{17}$.

Pliny includes Mucianus in his bibliographies to books 2, 3, 4, 5, 6, 7, 8, 9, $10,11,12,13,16,19,31,35,36$. He is duly adduced at least once in each of these volumes, except 6 and 10 . He is also brought into books 14 and 34, from whose bibliographies his name is absent. Pliny lists him indifferently as $\mathrm{Mu}-$ cianus or Licinius Mucianus. In about one quarter of the extracts, he is labelled ter consul. Mucianus' information is usually introduced with a verb such as prodit (his favourite, indifferently used in present and past tenses) or tradit. Nowhere does he give a title or even a reference to a specific book number. Indeed, were it not for his other formula, auctor est, his inclusion of Mucianus in the ranks of iis qui scripsere (XVI 2213), and the tribute to his expertise (XXXII 62), we might have been debating to what extent he had given his information to Pliny orally.

With the above remarks serving as preface, I now present in compact form the gist of each Plinian mention of Mucianus, with appropriate commentary,

16 For Pliny's use of his vast materials, see the recent studies by M. Beagon, Roman Nature: The Thought of Pliny the Elder, Oxford 1992, and J. Isager, Pliny on Art and Society. The Elder Pliny's Chapters on the History of Art, Odense 1991.

17 PIR ${ }^{2}$ suggests Rhodes, adducing Pliny XIX 12 . This deduction is equally frail, although it would put Mucianus at one with Tiberius in choice of an Eastern retreat, and Rhodes is about as prominent as Cyzicus in the $N H$. As we shall see, Mucianus is glimpsed in a number of other towns and cities. 
It is never absolutely clear to what extent Pliny's extracts comport his own paraphrases or the original phraseology of Mucianus: prodit, tradit, and company are deceptive pointers. On one occasion, Pliny does give what he says are Muciani verba, but even here there is modern dispute over how far in his text the actual quotation runs.

II 31. The water that flows from a spring in the temple of Liber on Andros acquires a flavour of wine every January 5. Pliny offers no other example of this phenomenon here, and there is no discussion. The verb credit here attached to Mucianus (as at XXXI 19, in a similar connection) might have been thought to imply some Plinian condescension, but he repeats the story (with some variation of the small details) at XXXI 16, there again adducing Mucianus, with apparent confidence in his veracity.

III 59. The Pomptine Marsh contains twenty-four cities. Again, no other example or source, and again no discussion. Despite labelling the claim as another miraculum of Italy, Pliny evinces no doubts. Here (it should be noted) is a case where Mucianus is cited for something that does not pertain to the East.

IV 66. Writing about Delos, Pliny observes that it alone of islands motum terrae non sensit ad M. Varronis aetatem: Mucianus prodidit bis concussam. Rackhan in his Loeb translation inserts a 'however' not in the Latin to suggest that Mucianus is correcting Varro. If so, Pliny is writing a bit loosely, unless tamen or some such word has fallen out. Mucianus might have been updating Varro: two earthquakes since his time. There is no mention of Herodotus' claim (VI 98) that Delos was shaken for the first and last time in 490.

IV 67. Mucianus octuples the dimensions of the island of Syros from those given by unspecified ancient writers; Pliny does not express any preference. He will be cited again in the $N H$ for such items, and tends to be the odd man out in his measurements.

IV 77. Mucianus differs from Agrippa, Artemidorus, Nepos, Varro, and unnamed veteres on the circumference of the Black Sea. All give discrepant figures, with Mucianus on the high side. Pliny again discloses no preference, sensibly observing (with other examples, not here featuring Mucianus) that conflicting views on such matters are common.

V 50. The dimensions of an Egyptian lake are almost doubled from the commonly given figure by Mucianus. This pronounced tendency of his to prefer bigger sizes may indicate that he was an author who liked to improve tales in their telling. Yet again, Pliny expresses no opinion ${ }^{18}$.

${ }^{18}$ But his adducing of Mucianus and citing of different authorities from ancient to modern times refutes the contention of F, Nosowad, «De locis communibus in Aegypti descriptione apud Plinium obviis", Meander 35, 1980, pp. 211-22 (in Polish, with résumé in Latin). 
V 83. Corbulo and Mucianus do not agree as to the precise source of the Euphrates. This passage was earlier discussed in terms of its possible implications for Mucianus' career. When Pliny (II 180) cites Corbulo for an eclipse in Armenia in the year 59, Mucianus is not mentioned, something that may weaken Syme's hypothesis. He is also absent from VI 23-9, a lengthy account of Armenia, prefaced by Pliny with the claim that his version will outdo older ones because it is based on Corbulo's narrative of recent events there, especially in regard to suppliant kings and royal hostages. We may well here be getting a glimpse of Pliny's own lost Historiae, written in continuation of Aufidius Bassus. With respect to the source of the Euphrates, the phrase sub radicibus montis quem Capotem appellat suggests that we are here getting Mucianus' own words.

$\mathrm{V}$ 128. Mucianus is the sole authority adduced for the leather pipes used to bring up fresh water from an undersea spring between Arados and the coast of Asia. Although Pliny elsewhere (XVI 224, XXXI 57, XXXV 159, XXXVI $121)$ reveals his own interest and expertise in aqueducts and their technology, this looks like the actual report of Mucianus.

$\mathrm{V}$ 132. Pliny lists without stating any preference various computations of the distance between Rhodes and Alexandria. They include that of Mucianus, as usual on the high (if not the highest) side. In view of the previous discussion of whether Mucianus retreated to Cyzicus or Rhodes, it is relevant to add that Pliny is here eloquent and expansive on the latter, beginning with the compliment pulcherrima est libera Rhodos. His own, or via Mucianus? The latter (it should be said) is not here cited for the circumference of the island, Pliny giving only his own figure and a smaller one from Isidore.

VII 36. Mucianus swore that he had personally seen cases of females turning into males at both Argos and Smyrna. This is the first of a number of mirabilia for which he understandably claims autopsy. Not to be outdone, Pliny (having insisted at the beginning of this section that ex feminis mutari in mares non est fabulosum) recounts how he too had seen such a thing, in Africa, when a bride turned into a man on her very wedding day (the husband's reaction is not reported). Given his Cyzicus theory, it is more than captious to point out that Syme mentions Mucianus at Argos but not at Smyrna. Could the latter city (mentioned on a number of occasions in the $\mathrm{NH}$ ) be a further candidate for Mucianus' place of retirement?

VII 159. Mucianus is the sole authority for the longevity of a certain Tempsis who attained one and a half centuries of life at Mount Tmolus Heights. This geographical precision and obscurity of place and person suggest autopsy, although the item is at once followed by a similar one drawn (Pliny emphasises) from the census of Claudius and other such records, hence Mu- 
cianus (whose zeal for documents has already been mentioned) could have got his story from the same kind of source.

VIII 6. In the course of his long disquisition on elephants, Pliny invokes Mucianus (and no one else) for two demonstrations of pachyderm intelligence: an ability to trace out a coherent sentence in Greek, and walking backwards off a ship at Puteoli to overcome fear at the length of the gangplank. This is one of the longer stretches from Mucianus, which might be indicative of his interests and the space he devoted to them. Since elephants evoke Africa and India, it should be observed that Mucianus claimed autopsy only for the Puteoli story, not the first one for which he is simply the auctor. Syme did not distinguish the two, lumping both in together as things reported de visu and indicative of the East.

VIII 201. From elephants to goats. Mucianus is brought in for an example of autopsy confirming caprine intelligence. Its setting has some affinity with the second elephant story. Two goats meet on a narrow bridge, cannot pass, cannot retreat... The solution? One lay down, the other walked over it. As very often with these extracts, Pliny gives no other source and does not discuss. He tells the tale in elegantly fashioned oratio obiqua. Whose words are they? The more conspicuous items of vocabulary suggest Pliny's own: on the combined evidence of the $T L L, O L D$, and Lewis \& Short, decumbere (of falling animals) is mainly in Pliny and Columella, praetenuis is especially frequent in Pliny, and reciprocatio is a favourite with himself and Aulus Gellius.

VIII 215. Mucianus is also to hand for the intelligence of apes, instancing their ability to play draughts and to detect fake nuts made of wax, and their emotional susceptibility to the phases of the moon. No autopsy is claimed, and no other source cited. Without any discussion, Pliny concurs on the mira sollertia of the apes.

IX 33. Having given a lengthy account of the clever ways in which dolphins help fishermen, Pliny adduces Mucianus for basic confirmation, albeit the latter's details vary somewhat. Pliny juxtaposes the two versions without comment. The restriction of Mucianus' testimony to the Iasian Gulf may suggest autopsy, though such is not here claimed.

IX 68. More geographical precision as Mucianus records the capture of a mullet weighing eighty pounds in the Red Sea. It is Pliny's only such item in this ichthyological section. He exploits it for an elaborate sarcasm that prefigures the fourth satire of Juvenal: what a price Roman epicures would have paid for this monster, had it been caught closer to home!

IX 80. A relatively lengthy sequence credits Mucianus for information on the murex and other purple fish, for an anecdote that has them stop a ship carrying orders from the old tyrant Periander to castrate some highborn youths, 
and for the agreeable supplement about the worship of these same creatures in the temple of Venus at Cnidus. Trebius Niger is adduced for some supporting and complementary details. Pliny includes all this matter without comment. There are various other allusions to Cnidus in the $\mathrm{NH}$; apart from occurring in various lists of cities, its distinctive trees and plants are singled out, as is its trend-setting elevated promenade.

IX 94. Another expansive sequence on fish life, this time the curious nauplius, a thing similar to the cuttle-fish. The information is credited to Mucianus' autopsy in the Propontis. The dozen or so lines of racy oratio obliqua contain little that is linguistically distinctive, except the verb carinare, a favourite with Pliny (the first author attested for it) but very rare thereafter. Also Plinian is the sentiment (of the creature's behaviour) nisi forte humana calamitas in causa est ${ }^{19}$.

IX 182. As postcript to a long account of the use by fishermen of the anthias fish as a decoy, Pliny subjoins a brief item from Mucianus about litigating fishmongers and the outcome of their case. The fish in question is associated by Pliny with the Swallow Islands off a promontory of Mt Taurus in "the rocky sea of Asia". There is no suggestion of autopsy, but Pliny's phraseology, addit Mucianus aestimata lite, leads one to wonder if the case had fallen under the latter's own jurisdiction. In the encircling sections, Pliny's tone sometimes seems to suggest a degree of scepticism or impatience. He introduces (IX 180) the topic of the anthias in the words nec de anthia pisce silere convenit ea quae plerosque aduerto credidisse, and opens and closes a paragraph (IX 183) on starfish by casting doubts on the methods and value of the research of claros sapientia auctores.

XI 167. To support his stories about teeth and their regrowth in aged individuals, Pliny appeals to Mucianus' claim to have seen a Samothracian named Zocles who grew a new set of teeth at the age of one hundred and four ${ }^{20}$. No other named authority appears in this sequence.

XII 9. A description of famous plane trees includes the account (already looked at) of Mucianus' banquet with eighteen companions inside a giant specimen, and his subsequent spending the night there. Pliny here introduces Mucianus not only as ter consul but as recently (nuper) the governor of Lycia (cf. XIII 88, also XXI 33 for Lycian saffron). Pliny waxes sarcastic throughout this entire sequence on giant planes, kicking off tam digna miraculo ut Licinius Mucianus (+ his titles) prodendum etiam posteris putauerit..., and following this anecdote with a similar one about Caligula, also incorporating a typical

${ }^{19}$ On the value of Pliny's account of this creature, see L. Casson, «Nauplius», $C Q 30$, 1980 , pp. 495-7.

20 Not one hundred and forty, as Rackham's Loeb has it in the English. 
epigram about mankind (natura hominum nouitatis auida) and the quintessentially Plinian gibe at Graeciae fabulositas.

XIII 88. Again introduced as thrice consul and lately in charge of Lycia, Mucianus is mentioned for his claim to have read in quodam templo a letter written on paper by Sarpedon at Troy. Pliny waxes sarcastic over this, quod eo magis miror, an expostulation similar to quod equidem miror at XVI 214, also about Mucianus.

XIV 54. Thanks to his being praesens in eo tractu, Mucianus was able to confirm details of the age, colour, and mixing of the wine of Maronea in Thrace. Syme laid some stress in this item in connection with his notion of Cyzicus as Mucianus' refuge, but despite the detail of his being there, Pliny adduces him as one of a crowd of sources, ex iis qui nuperrime prodidere, and largely as both complement and compliment to Homer, here thrice mentioned.

XVI 213. Again one of a number of recent writers (and in this case, visitors), Mucianus is singled out for his unique claims that the statue of Diana in her temple at Ephesus was made of vine wood, that it had never been altered, that the artist's identity was known (Endoeus is specified), and that the joins in the wood of the statue were treated with nard to keep them functional. Pliny is openly sceptical over the artist (quod equidem miror) and the matter of the joins (quas et ipsas esse modico admodum miror). He does, however, accept without qualification a final Mucianean detail about the use of cypress wood for the temple doors.

XIX 12. By contrast to the above, Pliny gratefully reports Mucianus' own researches into the construction of an ancient breastplate supposedly worn by the Egyptian king Amasis and preserved in the temple of Minerva at Lindus on Rhodes. This item is imported to convince readers who might be sceptical about the previous story here involving intricately strung threads in nets made for the recently deceased governor of Egypt ${ }^{21}$ — mirentur hoc ignorantes is Pliny's belligerent transition between the two items.

XXI 33. Mucianus (and no one else) is cited for his knowledge of transplanting saffron in Lycia. Given his tenure of office there, autopsy (not here specified) can obviously be assumed.

XXXI 16. After a stretch of nine books without mentioning him, Pliny revives his earlier (2.230) reference to Mucianus for the curious properties of a spring on Andros.

XXXI 19. Pliny cites without comment the depressing intelligence from Mucianus that those who drink the water of Cupid's Spring at Cyzicus lose

${ }^{21}$ T. Fulvius (or Julius) Lupus, whose death is pinpointed as not after March 25, 73, by O. W. Reinmuth, A Working List of the Prefects of Egypt 30 B.C. to 299 A.D., New Haven \& Toronto 1967, p. 10. 
their libido; his phraseology, ex quo potantes amorem deponere, might be designed as comically highflown, suggesting disbelief.

XXXII 62. This is the big one. Pliny prefaces his account of which countries breed oysters thus: sed dicemus aliena lingua quaeque peritissima huius censurae in nostro aevo fuit. sunt ergo Muciani uerba quae subiciam: Cyzicena maiora Lucrinis, dulciora Britannicis, suauiora Medullis, acriora Ephesis, pleniora Iliciensibus, sicciora Coryphantenis, teneriora Histricis, candidiora Circeiensibus. Nowhere else does Pliny offer any sort of tribute to Mucianus' expertise, and only here is he so explicit in advertising that the latter's actual words are quoted. Pace the Teubner editor Mayhoff, who suggested altering it to fuerit or fit, the closing fuit of the manuscripts is generally retained and used as evidence that Mucianus was recently deceased, an event that must have ocurred between 75 and 77 , in which latter year the $\mathrm{NH}$ was complete and dedicated to Titus. His death would be an obvious occasion for this unique tribute. In all the other allusions to him in Pliny, there is not a single complimentary adjective or adverb. And the tribute here does not, at best, go beyond a formal expression of regret. After all, Gellius opens a notice (IX 16) critical of Pliny by calling him aetatis suae doctissimus. Aliena lingua is hardly warm, and huius censurae could even be ironic, since this noun is frequently used by Pliny (e.g. IX 169, XIV 72) of the appraisal of food and wine. Connoisseurship of oysters was a theme for satire in Juvenal (IV 139-42). Syme was keen to link this item with his notion of Mucianus retiring to Cyzicus, but this does not necessarily follow: to the author of Priapea 75, this city was (v. 13) Cyzicos ostreosa. There is modern disagreement as to where precisely the quotation from Mucianus stops. Peter, for instance, extends it to Pliny's next sentence, sed his neque dulciora neque teneriora ulla esse compertum est. To my taste, this would make the extract self-contradictory, whilst compertum est suggests a new source. The Teubner incorporates the entire next section, about giant oysters found in the Indian Ocean during Alexander the Great's expedition, but this information is quite extraneous to what Mucianus says about individual qualities, also this new material is explicitly credited by Pliny to Alexandri rerum auctores.

XXXIV 36. Mucianus is quoted for the immense number of statues at Rhodes (three thousand there), Athens, Olympia, and Delphi. The precision for Rhodes may lend further support that it was there rather than Cyzicus that Mucianus sojourned. Pliny goes on to deride such titbits of trivia: quis ista mortalium persequi possit aut quis usus noscendi intellegatur?

XXXVI 131. Mucianus is the source for amazing information about sarcophagus stones at Assos in the Troad, also in Lycia and the East generally. No other source is given; Pliny appears to believe what he has here read. 
XXXVI 134. More astonishing stones, this time ones that give birth to others, on the authority of Mucianus and Theophrastus. Neither source is credited with autopsy (credunt is the verb used). Pliny records their views without comment, and passes on to other things.

This, then, is Pliny on Mucianus. Most of it is self-evident. The two most striking features are the irregular but growing notes on scepticism and disbelief that set in around book nine, and Pliny's generally cool ways of mentioning his name, even when in agreement. In his preface (22) to the $N H$, he excoriates modern writers (iuratissimis et proximis) for unacknowledged copying from the older ones. No names, no packdrill. However, Mucianus himself is twice (XIV 54, XVI 213) lumped in with unnamed contemporary sources: is he, then, to be reckoned as one of these offending plagiarists?

Pliny's varying attitudes to Mucianus could, of course, simply be the mark of an honest and selective scholar. This alone is worth pointing out, given the modern abuse so often heaped upon him. For most of the period during which the $N H$ was being written up, Mucianus was alive and powerful. He and his writings could hardly be left out. But the growing note of criticism, as the $\mathrm{NH}$ progresses, may well have been congenial to Titus, who looks to have become at odds with Mucianus ${ }^{22}$, and who cannot have relished the latter's constant bragging that it was he who had put Vespasian upon the throne ${ }^{23}$. Although only the royal family is extolled in the preface, Pliny's frequent naming of other writers therein makes the absence of Mucianus notable. The tensions with Titus, then his recent death, will have made the year 77 a particularly propitious moment for Pliny to complete and dedicate to Titus a work that not only acknowledged and complemented that of Mucianus but also (with some moments of ostentation) improved upon it.

BARRY BALDWIN

${ }^{22}$ See on this J. A. Crook, "Titus and Berenice», AJP 72, 1951, p. 165, where Titus is regardes as «dismayed at the lordly position of Mucianus"; he did not use Pliny in arriving at this conclusion.

${ }^{23}$ Tacitus, Hist. IV 4: id uero erga rem publicam superbum, erga principem contumeliosum, quod in manu sua fuisse imperium donatumque Vespasiano iactabat. 